\title{
The Use of Fine-Needle Aspiration (FNA) Cytology in Patients with Thyroid Nodules in Asia: A Brief Overview of Studies from the Working Group of Asian Thyroid FNA Cytology
}

\begin{abstract}
Chan Kwon Jung · SoonWon Hong ${ }^{1}$ Andrey Bychkov ${ }^{2} \cdot$ Kennichi Kakudo $^{3}$

Department of Hospital Pathology, Seoul St. Mary's Hospital, College of Medicine, The Catholic University of Korea, Seoul; ${ }^{1}$ Department of Pathology, Gangnam Severance Hospital, Yonsei University College of Medicine, Seoul, Korea; ${ }^{2}$ Department of Pathology, Faculty of Medicine, Chulalongkorn University, Bangkok, Thailand; ${ }^{3}$ Department of Pathology, Nara Hospital, Kindai University Faculty of Medicine, Nara, Japan
\end{abstract}

Received: October 12, 2017

Accepted: October 16, 2017

\section{Corresponding Author}

Chan Kwon Jung, MD

Department of Hospital Pathology, Seoul St. Mary's Hospital, College of Medicine, The Catholic

University of Korea, 222 Banpo-daero, Seocho-gu,

Seoul 06591, Korea

Tel: +82-2-2258-1622

Fax: +82-2-2258-1627

E-mail: ckjung@catholic.ac.kr
Ultrasound-guided fine-needle aspiration (FNA) cytology is the most widely used screening and diagnostic method for thyroid nodules. Although Western guidelines for managing thyroid nodules and the Bethesda System for Reporting Thyroid Cytopathology are widely available throughout Asia, the clinical practices in Asia vary from those of Western countries. Accordingly, the Working Group of Asian Thyroid FNA Cytology encouraged group members to publish their works jointly with the same topic. The articles in this special issue focused on the history of thyroid FNA, FNA performers and interpreters, training programs of cytopathologists and cytotechnicians, staining methods, the reporting system of thyroid FNA, quality assurance programs, ancillary testing, and literature review of their own country's products. Herein, we provide a brief overview of thyroid FNA practices in China, India, Japan, Korea, the Philippines, Taiwan, and Thailand.

Key Words: Thyroid; Cytology; Fine-needle aspiration; Asia; History; Methods; Survey
Fine-needle aspiration (FNA) cytology has been widely accepted as a safe, cost-effective, and accurate tool for the preoperative diagnosis of thyroid nodules. In the past, aspirations were performed only with the manual aid. Since FNA under ultrasound guidance proved to be more accurate for the detection of thyroid cancer, FNA should be performed under ultrasound guidance using a 23-, 25-, or 27-gauge needle for cytological evaluation. ${ }^{1,2}$ The wide use of FNA cytology for thyroid nodules has significantly decreased the rate of unnecessary surgery for benign thyroid nodules over the last three decades. ${ }^{1,3}$

Although North American and European guidelines for managing thyroid nodules and the Bethesda System for Reporting Thyroid Cytopathology (TBSRTC) are available throughout Asia, the clinical practices in Asia vary from those of Western countries in terms of disease incidence, diagnostic methods, availability of diagnostic tests, conservative management approach, national health insurance system, and governmental regulations on health care. Moreover, there is considerable variation among Asian countries due to the different rates of economic development and kinds of healthcare systems. Asian countries have increasingly reported their experiences of FNA of thyroid nodules using TBSRTC. Despite these efforts, Asian data on thyroid FNA have not been very well-organized so far. Accordingly, the Working Group of Asian Thyroid FNA Cytology established in 2016 has encouraged group members to publish their work jointly. ${ }^{4}$

In this special issue, seven articles from China, India, Japan, Korea, the Philippines, Taiwan, and Thailand jointly focused on the same topic regarding the history of thyroid FNA, FNA performers and interpreters, the training programs of cytopathologists and cytotechnicians, staining methods, the reporting system of thyroid FNA, quality assurance programs, and ancillary testing, added by the comprehensive review of publications released 





from the individual countries. ${ }^{5-11}$ Herein, we provide a brief overview of contemporary thyroid FNA practices based on the review articles from seven Asian countries.

\section{HISTORICAL ASPECTS OF THYROID FINE-NEEDLE ASPIRATION}

In the late 1920s, Hayes Martin and Edward Ellis performed aspiration biopsies using an 18-gauge needle for the cytological evaluation of thyroid lesions in the Memorial Hospital of New York. ${ }^{12}$ In 1952, thyroid aspiration cytology using a fine needle (diameter of 0.4-0.8 mm) was introduced by Nils Söderström in Sweden. ${ }^{13}$ Thyroid FNA was used in routine practice as an accurate test for distinguishing between benign and malignant thyroid nodules in Sweden since the 1950s. In the United States, FNA was not successfully used for the diagnosis of thyroid nodules before 1970s because of the clinician's preference for surgical biopsies, a lack of familiarity with the FNA procedure, and concerns about tumor seeding along the needle tract. ${ }^{14,15}$ After that time, thyroid FNA was reintroduced in the United States and became widely available in the $1980 \mathrm{~s}^{14}$

In Asia, thyroid FNA was introduced in China and Japan in the 1950s. ${ }^{9,10}$ In Korea, India, and Taiwan, thyroid FNA was introduced in the 1970s. ${ }^{5-711}$ Table 1 summarizes the brief history of thyroid FNA in seven Asian countries. ${ }^{5-11}$

\section{PERFORMERS AND INTERPRETERS OF THYROID FINE-NEEDLE ASPIRATION CYTOLOGY}

Since thyroid FNA was initially introduced by clinicians in most countries, interpretation of FNA cytology were mostly done by clinicians in the past, including endocrinologists, surgeons, and radiologists. In recent years, thyroid FNA has been performed under ultrasound guidance by clinicians in Japan, Korea, the Philippines, Taiwan, and Thailand. Chinese clinicians prefer an intraoperative frozen section rather than FNA for the diagnosis of thyroid nodules. 'Thyroid FNA is more frequently performed through palpation rather than ultrasound in India, Thailand, and the Philippines because of limited or delayed access to sonography. ${ }^{5,8,11}$ Table 2 summarizes the current practices of thyroid FNA performers and interpreters in seven Asian countries. ${ }^{5-11}$

\section{STAINING METHODS OF THYROID FINE-NEEDLE ASPIRATION CYTOLOGY SAMPLES}

The most widely used staining method for thyroid FNA specimens was Papanicolaou stain. Hematoxylin and eosin stain was favored by most Chinese pathologists. ${ }^{9}$ In India and Thailand, thyroid FNA samples were stained with a combination of two classical stains: alcohol-fixed smears were stained with Papani-

Table 2. Thyroid FNA performer and interpreter

\begin{tabular}{|c|c|c|}
\hline Country & Sampling & Interpretation \\
\hline China & $\begin{array}{l}\text { Primarily performed in endocrinology department in 1970-80s. } \\
\text { After 1987, thyroid FNA began to be popular in the pathology } \\
\text { department. } \\
\text { Thyroid FNA is not yet well accepted in China. } \\
\text { Most general hospital use frozen section as a diagnostic method } \\
\text { instead of thyroid FNA. }\end{array}$ & $\begin{array}{l}\text { Primarily performed in endocrinology department in 1970-80s. } \\
\text { After 1987, thyroid FNA began to be interpreted mainly } \\
\text { by pathologists. }\end{array}$ \\
\hline India & $\begin{array}{l}\text { Blind, palpation-guided FNAs performed by cytopathologists } \\
\text { US-guided FNA performed by clinicians or radiologists } \\
\text { Palpation-guided FNA appears to be the most commonly } \\
\text { used technique. }\end{array}$ & $\begin{array}{l}\text { Interpretation done by pathologists } \\
\text { Rapid on-site evaluation done in few academic institutions }\end{array}$ \\
\hline Japan & US-guided FNA usually performed by clinicians & Pathologists and clinicians with a board certification in cytopathology \\
\hline Korea & US-guided FNA usually performed by clinicians & Pathologists (cytopathologists) only interpret the thyroid FNA. \\
\hline Philippines & $\begin{array}{l}\text { Thyroid FNA procedure under US-guidance is performed } \\
\text { by pathologists and clinicians. }\end{array}$ & $\begin{array}{l}\text { Majority of pathologists report the diagnosis of cytology. } \\
\text { All interpretations are rendered by the pathologist. }\end{array}$ \\
\hline Taiwan & $\begin{array}{l}\text { Radiologists are the major performer of thyroid FNA. } \\
\text { US is used in most cases. }\end{array}$ & $\begin{array}{l}\text { Pathologists are the main diagnostician. } \\
\text { Before 1995, clinicians used to be both the performer and the } \\
\text { interpreter of thyroid FNA. }\end{array}$ \\
\hline Thailand & $\begin{array}{l}\text { FNA procedure is universally performed by clinicians. } \\
\text { In academic environment, trainees are frequently responsible } \\
\text { to perform FNA. }\end{array}$ & $\begin{array}{l}\text { Almost all cases of thyroid FNA cytology are signed out by certified } \\
\text { pathologists. } \\
\text { Cytotechnologists are not involved in thyroid FNA. } \\
\text { Few endocrinologists sign out thyroid FNA in academic centers. } \\
\text { Rapid on-site evaluation is rarely performed. }\end{array}$ \\
\hline
\end{tabular}

FNA, fine-needle aspiration; US, ultrasound. 
colaou stain and air-dried smears were stained with modified Giemsa stain (e.g., May-Grünwald-Giemsa stain or Diff-Quik stain). ${ }^{5,8}$ Table 3 summarizes the staining methods for thyroid FNA cytology specimens. ${ }^{5-11}$

\section{REPORTING SYSTEM OF THYROID FINE-NEEDLE ASPIRATION CYTOLOGY}

The reporting system of thyroid FNA cytology has improved significantly over the past 10 years with the introduction of TBSRTC. ${ }^{1,3}$ TBSRTC consists of six diagnostic categories in order to facilitate communication among cytopathologists and their clinical colleagues and to provide the risk of malignancy for each diagnostic category. ${ }^{3}$ After the introduction of TBSRTC, the system has been most widely accepted in China, India, Korea,

Table 3. Staining methods for thyroid fine-needle aspiration cytology specimens

\begin{tabular}{|c|c|}
\hline Country & Staining method \\
\hline China & $\begin{array}{l}\text { Wrights staining is popular in endocrine and clinical } \\
\text { laboratory department. } \\
\text { H\&E stain is common in pathology department. }\end{array}$ \\
\hline India & $\begin{array}{l}\text { Combination of Romanowsky (May-Grünwald-Giemsa stain) } \\
\text { and Papanicolaou stains is most widely used. } \\
\text { H\&E stain in few institutions }\end{array}$ \\
\hline Japan & $\begin{array}{l}\text { Papanicolaou stain is the most widely used. } \\
\text { Giemsa stain or Diff-Quik stain }\end{array}$ \\
\hline Korea & $\begin{array}{l}\text { Papanicolaou stain is the most widely used. } \\
\text { H\&E or Giemsa stain are used in some institutions. }\end{array}$ \\
\hline Philippines & $\begin{array}{l}\text { Papanicolaou stain } \\
\text { Diff-Quik stain } \\
\text { H\&E stain in cell blocks }\end{array}$ \\
\hline Taiwan & $\begin{array}{l}\text { Papanicolaou stain } \\
\text { Liu stain }\end{array}$ \\
\hline Thailand & $\begin{array}{l}\text { Combination of Papanicolaou and Diff-Quik stains are } \\
\text { most widely used. }\end{array}$ \\
\hline
\end{tabular}

H\&E, hematoxylin and eosin.

Table 4. Reporting system of thyroid FNA cytology

\begin{tabular}{|c|c|c|}
\hline Country & Before TBSRTC & After TBSRTC \\
\hline China & No data & TBSRTC is the most widely accepted. \\
\hline India & No data & TBSRTC is the most widely used. \\
\hline Japan & $\begin{array}{l}\text { General Rules for the Description of Thyroid Cancer (GRDTC): } \\
\text { adapted from the } 1996 \text { Papanicolaou Society } \\
\text { recommendations; published by the Japanese Society } \\
\text { of Thyroid Surgery in } 2005 \text { and updated in } 2006\end{array}$ & $\begin{array}{l}\text { GRDTC system is widely used. } \\
\text { Japanese system for thyroid FNA cytology published by the Japan } \\
\text { Thyroid Association (JTA) in 2013: used in several high-volume thyroid } \\
\text { surgery centers } \\
\text { TBSRTC is rarely used. }\end{array}$ \\
\hline Korea & $\begin{array}{l}\text { Not standardized and varied, but mostly followed guidelines } \\
\text { of the Papanicolaou Society of Cytopathology }\end{array}$ & TBSRTC is the most widely accepted. \\
\hline Philippines & Based on histopathologic terminology of thyroid disorder & TBSRTC is the most widely used. \\
\hline Taiwan & All investigators used different diagnostic categories. & TBSRTC or the 6-tier system corresponding to each Bethesda category \\
\hline Thailand & $\begin{array}{l}\text { Not standardized and varied, e.g., } \\
\text { thyroid FNA reporting was based on specific diagnosis } \\
\text { of the lesions. }\end{array}$ & TBSRTC is the most widely accepted. \\
\hline
\end{tabular}

FNA, fine-needle aspiration; TBSRTC, The Bethesda System for Reporting Thyroid Cytopathology. the Philippines, and Thailand. ${ }^{5,6,8,9}$ Other reporting systems for thyroid FNA cytology used in Asia were the General Rules for the Description of Thyroid Cancer by the Japanese Society of Thyroid Surgery, the Japanese System for Thyroid FNA Cytology by the Japan Thyroid Association, and the 6-tier System of Taiwan. ${ }^{7,10}$ Table 4 summarized the reporting system of thyroid FNA cytology before and after the introduction of TBSRTC. ${ }^{5-11}$

\section{NON-DIAGNOSTIC THYROID FINE-NEEDLE ASPIRATION}

Although ultrasound-guided thyroid FNA has high sensitivity and specificity in distinguishing benign from malignant thyroid nodules, in $1 \%-40 \%$ of cases, thyroid FNA is insufficient for diagnosis and is categorized as non-diagnostic according to TBSRTC. ${ }^{16}$ The non-diagnostic FNA cytology by TBSRTC includes virtually acellular specimens (requiring the presence of at least six groups of well-visualized follicular cells with each group containing at least 10 well-preserved epithelial cells), cystic fluid only, and other specimens (obscuring blood, crushed artifacts, poor clotting artifacts, air drying artifacts, overly thick smears, etc.). ${ }^{3}$ In the Japanese system, thyroid FNA with "cystic fluid only" is classified as benign rather than non-diagnostic. ${ }^{10,17}$ In Taiwan, a paucicellular specimen with fewer than six groups of ten benign follicular cells is considered benign if it contains more than 50 follicular cells in total or consists of degenerative hemorrhagic cyst fluid and scant benign follicular cells. ${ }^{7}$

Table 5 summarizes the criteria and rate of non-diagnostic thyroid FNA. ${ }^{5-11}$ A high rate of non-diagnostic aspirates was reported from several teaching hospitals in the Philippines and Thailand, which was linked to the training activity of unskilled residents and limited access to ultrasound guidance. ${ }^{8,11}$ 


\section{LIQUID-BASED CYTOLOGY AND ANCILLARY TESTS}

In Korea, the use of liquid-based cytology in thyroid FNA was adopted in 2008 and became widely used since $20100^{6,18} \mathrm{In}$ Taiwan, liquid-based cytology in thyroid FNA was first introduced in 2014 and then became commonly used. ${ }^{7}$ However, liquidbased cytology has not been made widely available for thyroid FNA in other countries. ${ }^{5,8-11}$

Core needle biopsy as an alternative to thyroid FNA has been used mainly in Korea whereas in other countries, this biopsy is performed only in a few institutions. ${ }^{5-10}$

Immunocytochemistry generally has limited applications for the diagnosis of thyroid FNA in Asian countries. Although molecular testing has been useful for the diagnosis of indeterminate thyroid FNA, it is often not practical for most clinical laboratories and is generally not covered by health insurance in Asia. ${ }^{5-11}$

Table 6 summarizes the ancillary tests in thyroid FNA cytology. ${ }^{5-11}$

Table 5. Non-diagnostic thyroid FNA

\begin{tabular}{|c|c|c|}
\hline Country & Criteria for non-diagnostic FNA & Incidence of non-diagnostic FNA \\
\hline China & TBSRTC & $3.6 \%$ at one institution \\
\hline India & $\begin{array}{l}\text { TBSRTC } \\
\text { Different criteria in a study: } 10 \text { clusters are needed with each having more than } 20 \text { cells; } \\
\text { in case of presence of tissue fragments, minimum number of fragments required is } 8 . \\
\text { Royal College of Pathologists guidelines in one study }\end{array}$ & $7.4 \%(0.5 \%-25.7 \%)$ from 38 studies \\
\hline Japan & $\begin{array}{l}\text { General Rules for the Description of Thyroid Cancer system } \\
\text { Japanese system }\end{array}$ & $10 \%$ according to the Japanese system \\
\hline Korea & TBSRTC & $12.4 \%(0 \%-32.6 \%)$ from 12 institutions \\
\hline Philippines & TBRSTC & $1.3 \%$ and $23.1 \%$ from 2 studies \\
\hline Taiwan & Variable but different from TBRSTC ${ }^{a}$ & $8 \%$ at one institution \\
\hline Thailand & TBSRTC & $12.7 \%-47.6 \%$ from three institutions \\
\hline
\end{tabular}

FNA, fine-needle aspiration; TBSRTC, the Bethesda System for Reporting Thyroid Cytopathology.

aMost Taiwan pathologists consider that the specimen is negative, but not non-diagnostic when there are less than six groups but more than 50 follicular cells in total or a degenerative hemorrhagic cyst with scant benign follicular cells.

Table 6. Ancillary tests in thyroid FNA cytology

\begin{tabular}{|c|c|c|c|c|}
\hline Country & Liquid-based cytology & Core needle biopsy & Immunocytochemistry & Molecular or other testing \\
\hline$\overline{C h i n a}$ & Not commonly used & No data & No data & $\begin{array}{l}\text { Amplification refractory mutation system } \\
\text { for BRAF V600E is the most popular } \\
\text { technique. } \\
\text { Next generation sequencing is not well } \\
\text { accepted. }\end{array}$ \\
\hline India & $\begin{array}{l}\text { Has been used in some } \\
\text { institutions as addition } \\
\text { to conventional smears }\end{array}$ & $\begin{array}{l}\text { Limited applicability and } \\
\text { acceptability }\end{array}$ & $\begin{array}{l}\text { Limited applicability and } \\
\text { acceptability }\end{array}$ & Limited applicability and acceptability \\
\hline Japan & $\begin{array}{l}\text { Used in some laboratories, } \\
\text { but is not widely available }\end{array}$ & Rarely performed & No data & $\begin{array}{l}\text { BRAF testing is uncommon practice and } \\
\text { not covered by national health insurance } \\
\text { system. } \\
\text { Thyroglobulin and/or calcitonin in FNA } \\
\text { needle washings is often used in thyroid } \\
\text { or lymph node aspirates. }\end{array}$ \\
\hline Korea & $\begin{array}{l}\text { Became popular since } \\
2010 \\
\text { Used in } 68 \% \text { institutions } \\
\text { in } 2016\end{array}$ & Widely used & $\begin{array}{l}\text { Not routinely used but can be } \\
\text { applied in specific cases }\end{array}$ & $\begin{array}{l}\text { BRAF testing is used. } \\
\text { Thyroglobulin and/or calcitonin in FNA } \\
\text { needle washings is often used in thyroid } \\
\text { or lymph node aspirates. }\end{array}$ \\
\hline Philippines & Not used & No data & Rarely performed & $\begin{array}{l}\text { Not covered by health care insurance } \\
\text { Referred to outsource/abroad facilities } \\
\text { if patients agree to pay }\end{array}$ \\
\hline Taiwan & $\begin{array}{l}\text { Became popular since } \\
2014\end{array}$ & Rarely performed & $\begin{array}{l}\text { In some institutions, } \\
\text { immunocytochemical staining } \\
\text { is used. }\end{array}$ & $\begin{array}{l}\text { In some institutions, molecular testing } \\
\text { is used. }\end{array}$ \\
\hline Thailand & Rarely used & Very uncommon & Available, but rarely performed & Rarely used due to limited availability \\
\hline
\end{tabular}

FNA, fine-needle aspiration. 


\section{TRAINING PROGRAM}

Asian pathologists receive a certification in pathology and cytopathology after completing residency training and passing board examinations, and usually practice both surgical pathology and cytopathology. Training programs for cytotechnicians have been well organized in Japan, Korea, and Taiwan. Certified cytotechnicians screen thyroid FNA cytology, but are not eligible to declare a final diagnosis without supervision by a pathologist. Table 7 summarizes the training programs for cytopathologists and cytotechnicians. ${ }^{5-11}$

\section{QUALITY CONTROL AND QUALITY ASSURANCE PRACTICES}

Quality control in cytology includes all activities to improve the performance of the test from the time of specimen collection until the cytology report is completed. Quality assurance defined by the College of American Pathologists includes quality review activities and systematic monitoring of quality control results

Table 7. Training programs for cytopathologists and cytotechnicians

\begin{tabular}{|c|c|c|}
\hline Country & Cytopathologist & Cytotechnician \\
\hline China & No data & No data \\
\hline India & No data & $\begin{array}{l}\text { Indian Academy of Cytologists conducts exam for cytotechnicians and } \\
\text { cytotechnologists. } \\
\text { Few centers run cytotechnician and cytotechnologist training programs } \\
\text { for certification. } \\
\text { Only limited institutions have cytoscreeners. }\end{array}$ \\
\hline Japan & $\begin{array}{l}\text { Pathologists have dual boards of anatomical pathology } \\
\text { and cytopathology. } \\
\text { Clinicians also have board of cytopathology. }\end{array}$ & $\begin{array}{l}\text { JSCC certification } \\
\text { Candidate 1: medical technologist after 3-year course at a vocational } \\
\text { school or 4-year course at a medical technology school, 1-year work } \\
\text { experience requirements at the cytology laboratory of a teaching hospital } \\
\text { Candidate 2: 4-year college graduate }\end{array}$ \\
\hline Korea & $\begin{array}{l}\text { Pathology residents must pass the exam in both fields } \\
\text { of surgical pathology and cytolopathology to get } \\
\text { the pathology board. } \\
\text { For board certificated pathologists, there is annual } \\
\text { requirement for continuing cytology education activities. }\end{array}$ & $\begin{array}{l}\text { Nationwide cytotechnician education program began under the auspices } \\
\text { of the World Health Organization in } 1981 . \\
\text { After 2-year pathology or cytology laboratory practice as a technician, } \\
\text { 1-year training program at a National Cancer Center and } \\
\text { certification exam }\end{array}$ \\
\hline Philippines & $\begin{array}{l}\text { Formal cytopathology training programs are not offered. } \\
\text { Conferences in cytopathology are embedded } \\
\text { in the training program of anatomic pathology. }\end{array}$ & No training programs \\
\hline Taiwan & $\begin{array}{l}\text { At least } 3 \text { months of cytology screening and sign-out } \\
\text { practice } \\
\text { Pathology residents are required to attend a 2-week } \\
\text { intensive course. } \\
\text { Pathology residents should pass both exams of } \\
\text { surgical pathology and cytolopathology to get } \\
\text { the pathology board. } \\
\text { For board certificated pathologists, there is annual } \\
\text { requirement for continuing cytology education } \\
\text { activities. }\end{array}$ & $\begin{array}{l}\text { One-year on-site training at a qualified training institution and a final exam } \\
\text { There are } 12 \text { qualified institutions for cytotechnologist training in Taiwan. }\end{array}$ \\
\hline Thailand & $\begin{array}{l}\text { General cytopathology and thyroid cytology are the } \\
\text { essential parts of the training program for anatomic } \\
\text { pathology residents. }\end{array}$ & No data \\
\hline
\end{tabular}

JSCC, Japanese Society of Clinical Cytology. to provide confidence that all quality control systems are functioning properly and quality requirements are fulfilled. ${ }^{19}$ Quality control materials in thyroid FNA should include the distribution of each diagnostic category, histologic outcomes of FNA diagnostic categories, rate of surgical follow-up, and risk of malignancy calculated using the total number of each diagnostic category with and without surgical follow-up.

Quality improvement programs in Asian countries are organized by local societies of cytology and/or pathology. Table 8 summarizes the quality assurance and quality control programs in thyroid FNA cytology. ${ }^{5-11}$

\section{CONCLUSION}

The purpose of the recently established Working Group of Asian Thyroid FNA Cytology is to promote communication and share practices among pathologists, cytopathologists, and clinicians dealing with thyroid FNA in Asia. In this special issue, we presented for the first time a single volume collection of contemporary reviews on Asian practices of thyroid FNA. Despite
Cytotechnician
No data
Indian Academy of Cytologists conducts exam for cytotechnicians and
cytotechnologists.
Few centers run cytotechnician and cytotechnologist training programs
for certification.
Only limited institutions have cytoscreeners.
JSCC certification
Candidate 1: medical technologist after 3-year course at a vocational
school or 4-year course at a medical technology school, 1-year work
experience requirements at the cytology laboratory of a teaching hospital
Candidate 2: 4-year college graduate
Nationwide cytotechnician education program began under the auspices
of the World Health Organization in 1981.
After 2-year pathology or cytology laboratory practice as a technician,
1-year training program at a National Cancer Center and
certification exam
No training programs
One-year on-site training at a qualified training institution and a final exam
There are 12 qualified institutions for cytotechnologist training in Taiwan.
No data 
Table 8. Quality assurance and quality control programs in thyroid FNA cytology

\begin{tabular}{|c|c|c|}
\hline Country & Internal program & Nationwide external program \\
\hline$\overline{\text { China }}$ & No data & No data \\
\hline India & No data & $\begin{array}{l}\text { External Quality Assurance Programme of the Indian Academy } \\
\text { of Cytologists } \\
\text { Only straightforward diagnose are assessed for thyroid FNA quality } \\
\text { control. }\end{array}$ \\
\hline Japan & No data & No data \\
\hline Korea & $\begin{array}{l}\text { Accuracy assessment by cyto-histological correlations } \\
\text { Annual reports on quality control of thyroid FNA } \\
\text { have been published since } 1996 \text {. }\end{array}$ & $\begin{array}{l}\text { Cytology proficiency testing in the Korean Society for Cytopathology } \\
\text { has been performed since } 1996 . \\
\text { National quality control program in the Korean Society of Pathologists } \\
\text { began in } 1999 .\end{array}$ \\
\hline Philippines & $\begin{array}{l}\text { Self-review } \\
\text { Intradepartmental referral to another pathologist } \\
\text { All thyroid surgeries with previous FNA done in the same } \\
\text { hospital are reviewed. }\end{array}$ & $\begin{array}{l}\text { In the process of developing an external quality assurance program } \\
\text { in cytopathology }\end{array}$ \\
\hline Taiwan & No data & $\begin{array}{l}\text { Currently there is no authoritative quality assurance program } \\
\text { for external evaluation. }\end{array}$ \\
\hline Thailand & No data & $\begin{array}{l}\text { External quality assurance program for Thai pathologists is set up and } \\
\text { supported by the Thai Society of Cytology. } \\
\text { No nationwide thyroid FNA cytologic-histological correlation program }\end{array}$ \\
\hline
\end{tabular}

FNA, fine-needle aspiration.

most countries adopting Western systems and guidelines and incorporated them into their national systems early, there remains local variation which should be considered when doing comparisons between Asian and Western countries, and among Asian countries. We hope that these reports from Asia will encourage further studies on thyroid FNA cytology to improve the diagnosis of thyroid nodules and subsequently provide optimal care for patients with thyroid nodules in Asia.

\section{Conflicts of Interest}

No potential conflict of interest relevant to this article was reported.

\section{Acknowledgments}

We would like to acknowledge all the members of the Working Group of Asian Thyroid FNA Cytology. This work was supported by a grant (HI16C2013) from the Korean Health Technology R\&D Project, Ministry of Health \& Welfare, Republic of Korea.

\section{REFERENCES}

1. Haugen BR, Alexander EK, Bible KC, et al. 2015 American Thyroid Association management guidelines for adult patients with thyroid nodules and differentiated thyroid cancer: the American Thyroid Association Guidelines Task Force on Thyroid Nodules and Differentiated Thyroid Cancer. Thyroid 2016; 26: 1-133.

2. Paschke R, Cantara S, Crescenzi A, Jarzab B, Musholt TJ, Sobrinho Simoes M. European Thyroid Association guidelines regarding thyroid nodule molecular fine-needle aspiration cytology diagnostics. Eur Thyroid J 2017; 6: 115-29.

3. Cibas ES, Ali SZ; NCI Thyroid FNA State of the Science Conference. The Bethesda System For Reporting Thyroid Cytopathology. Am J Clin Pathol 2009; 132: 658-65.

4. Bychkov A, Kakudo K, Hong S. Current practices of thyroid fineneedle aspiration in Asia: a missing voice. J Pathol Transl Med 2017; 51:517-20.

5. Agarwal S, Jain D. Thyroid cytology in India: contemporary review and meta-analysis. J Pathol Transl Med 2017; 51: 533-47.

6. Cha YJ, Pyo JY, Hong S, et al. Thyroid fine-needle aspiration cytology practice in Korea. J Pathol Transl Med 2017; 51: 521-7.

7. Hang JF, Hsu CY, Lai CR. Thyroid fine-needle aspiration in Taiwan: the history and current practice. J Pathol Transl Med 2017; 51: 560-4.

8. Keelawat S, Rangdaeng S, Koonmee S, Jitpasutham T, Bychkov A. Current status of thyroid fine-needle aspiration practice in Thailand. J Pathol Transl Med 2017; 51: 565-70.

9. Liu Z, Liu D, Ma B, et al. History and practice of thyroid fine-needle aspiration in China, based on retrospective study of the practice in Shandong University Qilu Hospital. J Pathol Transl Med 2017; 51: 528-32.

10. Satoh S, Yamashita H, Kakudo K. Thyroid cytology: the Japanese system and experience at Yamashita Thyroid Hospital. J Pathol Transl Med 2017; 51: 548-54.

11. Abelardo AD. Thyroid fine-needle aspiration practice in the Philippines. J Pathol Transl Med 2017; 51: 555-9.

12. Martin HE, Ellis EB. Biopsy by needle puncture and aspiration. Ann Surg 1930; 92: 169-81.

13. Soderstrom N. Puncture of goiters for aspiration biopsy. Acta Med 
Scand 1952; 144: 237-44.

14. Cramer H. Fine-needle aspiration cytology of the thyroid: an appraisal. Cancer 2000; 90: 325-9.

15. Diamantis A, Magiorkinis E, Koutselini H. Fine-needle aspiration (FNA) biopsy: historical aspects. Folia Histochem Cytobiol 2009; 47: 191-7.

16. Lee SH, Kim MH, Bae JS, Lim DJ, Jung SL, Jung CK. Clinical outcomes in patients with non-diagnostic thyroid fine needle aspiration cytology: usefulness of the thyroid core needle biopsy. Ann Surg Oncol 2014; 21: 1870-7.
17. Takada N, Hirokawa M, Suzuki A, Higuchi M, Kuma S, Miyauchi A. Reappraisal of "cyst fluid only" on thyroid fine-needle aspiration cytology. Endocr J 2017; 64: 759-65.

18. Jung CK, Lee A, Jung ES, Choi YJ, Jung SL, Lee KY. Split sample comparison of a liquid-based method and conventional smears in thyroid fine needle aspiration. Acta Cytol 2008; 52: 313-9.

19. Medicare, Medicaid and CLIA programs: regulations implementing the Clinical Laboratory Improvement Amendments of 1988 (CLIA)-HCFA: final rule with comment period. Fed Regist 1992; 57: 7002-186. 